\title{
FISH SPECIES DIVERSITY, FISHING GEARS AND CRAFTS FROM THE BURIGANGA RIVER, DHAKA
}

\author{
Mohammad Abdul Baki, Md. Muzammel Hossain*, \\ Naser Ahmed Bhouiyan and Md. Asaduzzaman \\ Department of Zoology, Jagannath University, Dhaka-1100, Bangladesh
}

\begin{abstract}
Fish species, fishing gear and crafts in the most polluted river Buriganga were inventorial. During December, 2012 to November, 2013, a total of 56 fish species belonging to 20 families and 9 orders were recorded. Cypriniformes observed to be the most dominant order with 18 species $(32 \%)$. The highest fish diversity was recorded during monsoon season, and lowest during winter. Maximum diversity variance $(7.616 \pm 2.76 \mathrm{Sd})$ observed in the monsoon season for 56 species (220 individuals). Also 12 different types of gears of two categories (active and passive) and two types of crafts were observed to be used for fishing in the study area. The highest number of species of fishes $(n=56)$ recorded in August and lowest $(n=3)$ in April and May 2013. Strong correlation between water depth and number of fish species $(r=0.74)$ and fishing activities $(\mathrm{r}=0.96)$ was observed.
\end{abstract}

Key words: Fish diversity, fishing gear, craft, Buriganga river.

\section{INTRODUCTION}

The River Buriganga running by the side of the Dhaka city, the capital of Bangladesh, which is a megacity of about 12 million people. Intensive human intervention, rapid industrialization, unplanned urbanization and population pressure around the river are main causes for its pollution (Moniruzzaman et al. 2009). The River Buriganga is highly polluted river of Bangladesh (Sarker 2005, Nouri et al. 2009). It is increasingly being polluted with the city's thousands of industrial units and sewerage lines dumping huge volumes of toxic wastes into it day and night (Islam et al. 2006). The Department of Environment (DoE) identified 249 factories along the River Buriganga (Sarker 2005). Most importantly, the quality of the Buriganga river water has been deteriorating. The large input of organic matter to aquatic flood plain habitats may reduce dissolved oxygen and result in the emigration or death of a great number of fishes (Winemiller 1989).

It is often claimed that freshwater ecosystems are the most endangered ecosystems in the world (Sala et al. 2000) affecting both species diversity and their abundance. Throughout the last century, freshwater fish are one of the

*Author for correspondence: <muzammel3@gmail.com>.

(c) 2017 Zoological Society of Bangladesh DOI: http://dx.doi.org/10.3329/bjz.v45i1.34190 
most threatened taxonomic groups (Darwall and Vie 2005) because of their high sensitivity to the quantitative and qualitative alteration of aquatic habitat due to intensive anthropogenic activities (Laffaille et al. 2005, Kang et al. 2009, Sarkar et al. 2008). As a consequence, many fish species have become highly endangered, particularly in rivers. However, most of the fish populations have seriously declined in rivers and streams of Bangladesh due to over exploitation augmented by various ecological changes and degradation of the natural habitats (Hossain et al. 2012a,b). Subsequently they are often used as bioindicators for assessment of water quality, river network connectivity or flow regime (Chovance et al. 2003). Nowadays, fish biodiversity and management of associated habitats is a great challenge (Dudgeon et al. 2006). In addition, the conservation of aquatic biodiversity has gained great ecological importance over recent years (Hossain et al. 2012a). Several studies of Buriganga river on heavy metal concentrations in fishes (Aleya et al. 2013, Ahmed et al. 2016), water (Mohiuddin et al. 2011) and sediment (Saha and Hossain 2011, Mohiuddin et al. 2011), Ecological health (Ali et al. 2008), bacterial load and chemical pollution (Mihir et al. 2009), restoration of Buriganga (Khorshed 2008), have been centered. However, synthesis and analysis or assessments of fish biodiversity are highly limited for this river. Moreover, this study could not find out any publication on fish diversity of Buriganga river using different web based search engine. Therefore, this study attempted to collect information and documentation on fish diversity and state of Buriganga river ecology.

\section{MATERIAL AND METHODS}

Study area: The River Buriganga is situated at the south-western periphery of Dhaka city. The average depth is 25 feet $(7.6 \mathrm{~m})$ and maximum depth is 58 feet $(18 \mathrm{~m})$. Study was carried out approximately $18.5 \mathrm{~km}$ in the river. The study was restricted to three main parts of the site: Bangladesh- China friendship bridge (Postoghola bridge) to Babu bazar bridge $=\mathrm{A}$ site, $\mathrm{Babu}$ bazar bridge to Basilla bridge $=\mathrm{B}$ and Basilla bridge to Amin bazar bridge $=\mathrm{C}$. Study area started from Posthogola bridge point $\left(90^{\circ} 26^{\prime} 12^{\prime \prime} \mathrm{E}\right.$ and $\left.23^{\circ} 40^{\circ} 25^{\prime \prime} \mathrm{N}\right)$ and ending Amin bazar bridge $\left(90^{\circ} 20^{\circ} 12^{\prime \prime} \mathrm{E}\right.$ and $\left.23^{\circ} 46^{\circ} 25^{\prime \prime} \mathrm{N}\right)$ (Fig. 1). Geographical position confirmed by GPS meter Model: Magellan GPS 320.

Study period: Present inventory survey was carried out during December, 2012 to November, 2013 in the Buriganga river. Survey was conducted for two days per month/fortnightly. Survey was usually made between 7.00 a.m. and 5.00 p.m. 


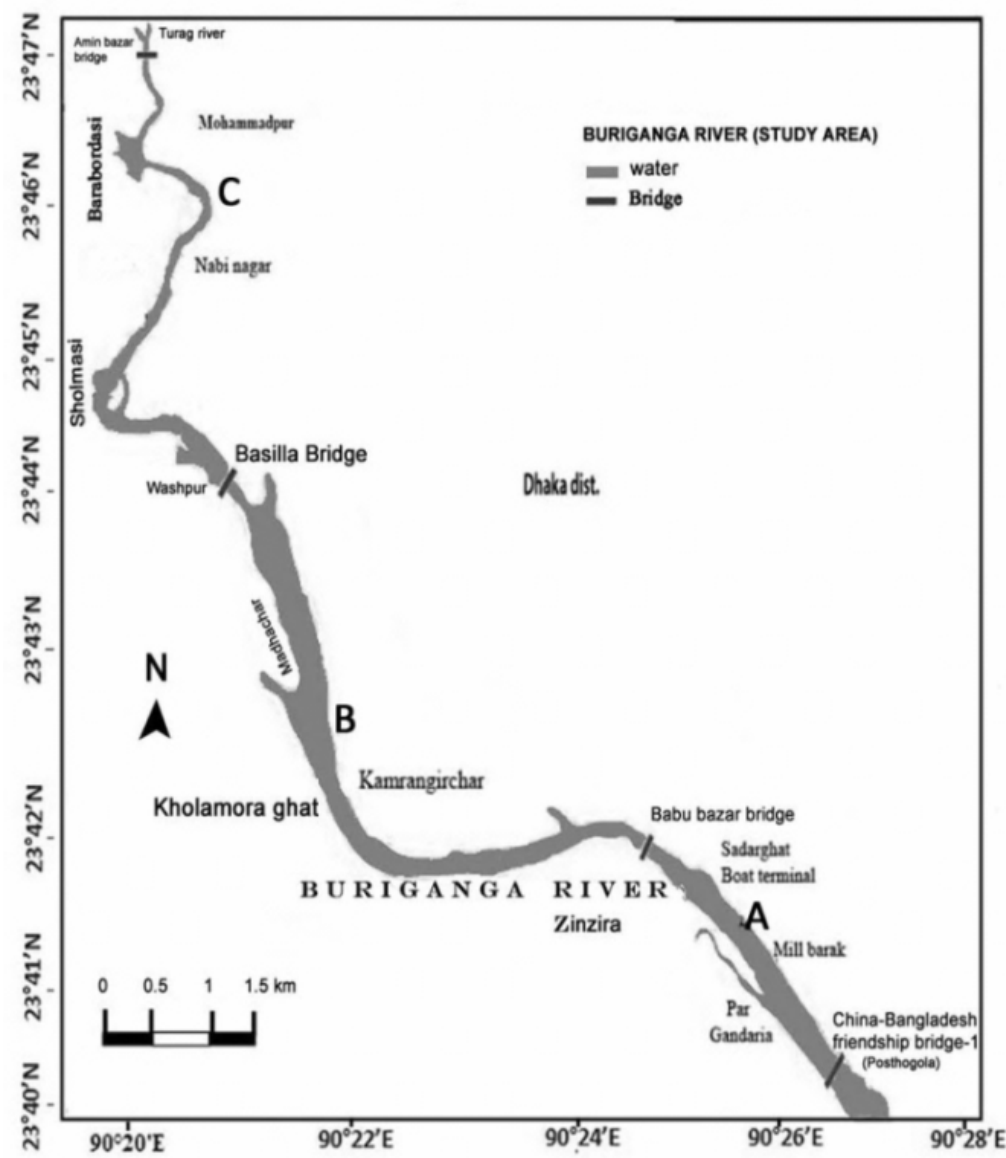

Fig. 1. Study area from China-Bangladesh friendship Bridge-1 to Amin bazar bridge in the river Buriganga.

Survey procedure for data collection: Boat base and questioner survey were held continuously in the river through a biological team. Team member used digital camera, measurement tape, spring balance, polythene bags, data shit, pencil, rubber band, map and other field logistics. Detailed information on catch by species and different types of gear and craft were recorded while fishermen were harvesting fish in the river and different ages of fishermen were interviewed on the gears and also questions about the local names, mode of operation, species caught, fishing starting and ending time. Fish species, fishing gears and crafts were observed and fish samples were collected directly from the fishing sites along the river soon after they were caught to confirm their identification. Fish specimen were transported to the laboratory for the identification and preserved in $10 \%$ formalin for further observation. Fish species, gear and craft 
photographs were also taken. Fish species weighed by spring balance and length size recorded by scale during the interview time of fisherman.

Identification and hydrological time: Fish identification, common and scientific names used throughout this study are in accordance with pictorial books by (Rahman 1989, Siddiqui et al. 2007) and gear indentified by Ahmed (1962). Hydrological year can be divided into four seasons: (i) Rising flood (premonsoon): May-June. (ii) Full flood (monsoon): July-September. (iii) Flood drawdown (post monsoon): October-November. (iv) dry season (winter): December-April (FAP - 17, Vol. No. 10, 1994). Bangladesh Water Development Board (BWDB) set up a water level monitoring station at Buriganga river for forecasting the flood situation of Dhaka city. This station was located at $90^{\circ} 26^{\prime} 12^{\prime \prime} \mathrm{E}$ and $23^{\circ} 40^{\circ} 25^{\prime \prime} \mathrm{N}$ for the daily monitoring of the water level of the Buriganga river which included a staff gages. Therefore, this study collected the daily water depth data during study period from BWDB office, 72 Green Road, Farmgate, Dhaka, Bangladesh.

Statistical analysis: Data analysis for fish diversity, their abundance and distribution in the river system was carried out using MS excel. Rarefaction curves, species abundance plot (rank) distribution for the collected fish has been prepared using biodiversity pro software (Ver. 2015). The fish diversity index was calculated as per Shannon-Weiner Index. Where $\mathrm{H}^{\prime}=$ Shannon-Weiner diversity index, $\mathrm{ni}=$ Number of individuals, $\mathrm{N}=$ Total number of species, $\mathrm{D}=$ Diversity. Follow the formula.

$$
\mathbf{H}^{\prime}=-\sum_{i=1}^{S} \frac{n i}{N} \ln \frac{n i}{N} \quad D=1-\frac{\sum_{i=1}^{5} n i(n i-1)}{N(N-1)}
$$

\section{RESULTS AND DISCUSSION}

The main ecological and hydrological features of the Buriganga river basin depend on the flood pulse. The measurement of water depth, increased and depletion of river water in different months are shown in Fig. 2. Depth of the water level starts to rise in May due to pre-monsoon water. This initial increase in discharge is followed by very sharp rise occurring in June and drop in July but reach flood peaks in August and September. This is the result of monsoon. Depth of water normally decreases after peaks of September onwards, reaching a minimum level in March. Water depth data clearly shown that water depth lowers in the winter and pre-monsoon periods compared to monsoon period. There is no change of water depth in the Buriganga river during winter period due to reduced flow of water in this period. A total of 56 fish species belonging to 41 genera, 20 families and 9 orders have been identified and recorded with total 
length, weight from the upper Buriganga river (Table 1). Water level gradually increases with maximum number of fish species during July, 2013 to November, 2013. Maximum total length $42 \mathrm{~cm}$ and weight $1500 \mathrm{gm}$ of fish individual recorded. The fish species have been classified in terms of "Not Evaluate" "List

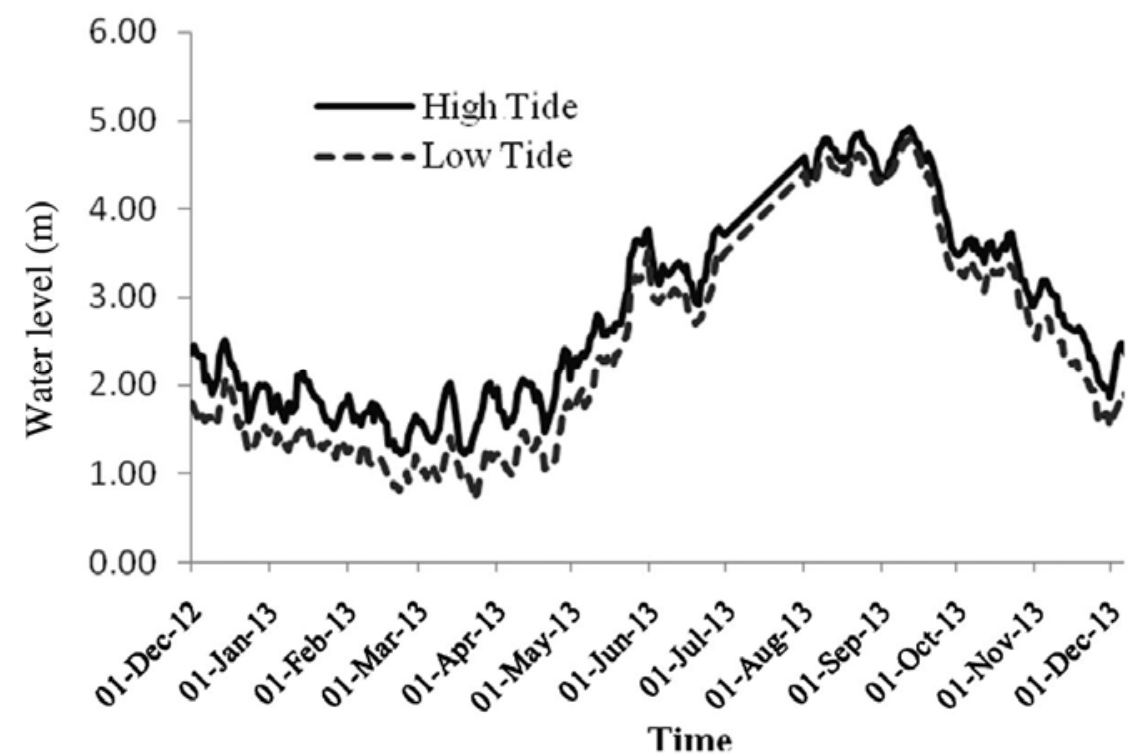

Fig. 2. Yearly water level fluctuation at Dhaka Mill Barak in the Buriganga river.

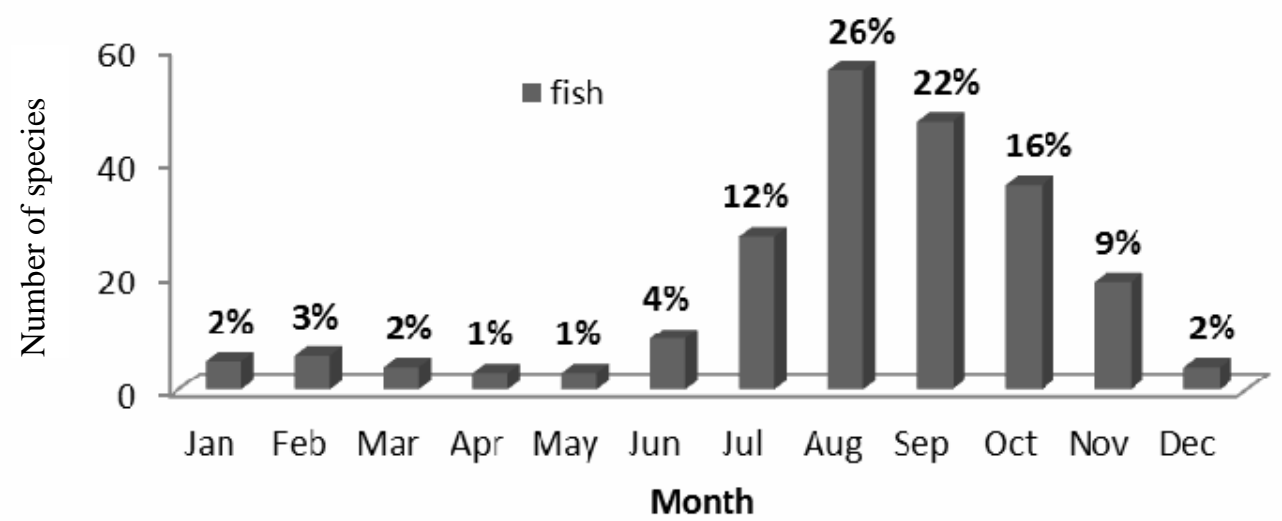

Fig. 3. Monthly percentage of fish species recorded from the Buriganga river.

Concern" "Endangered", "Critically Endangered", or "Vulnerable" fish species following IUCN status 2015 (Table 1). In August, number of species reached 56, afterward number of species declined in September. Clear seasonal patterns in the variation of total number of species was recorded (Fig. 3). 


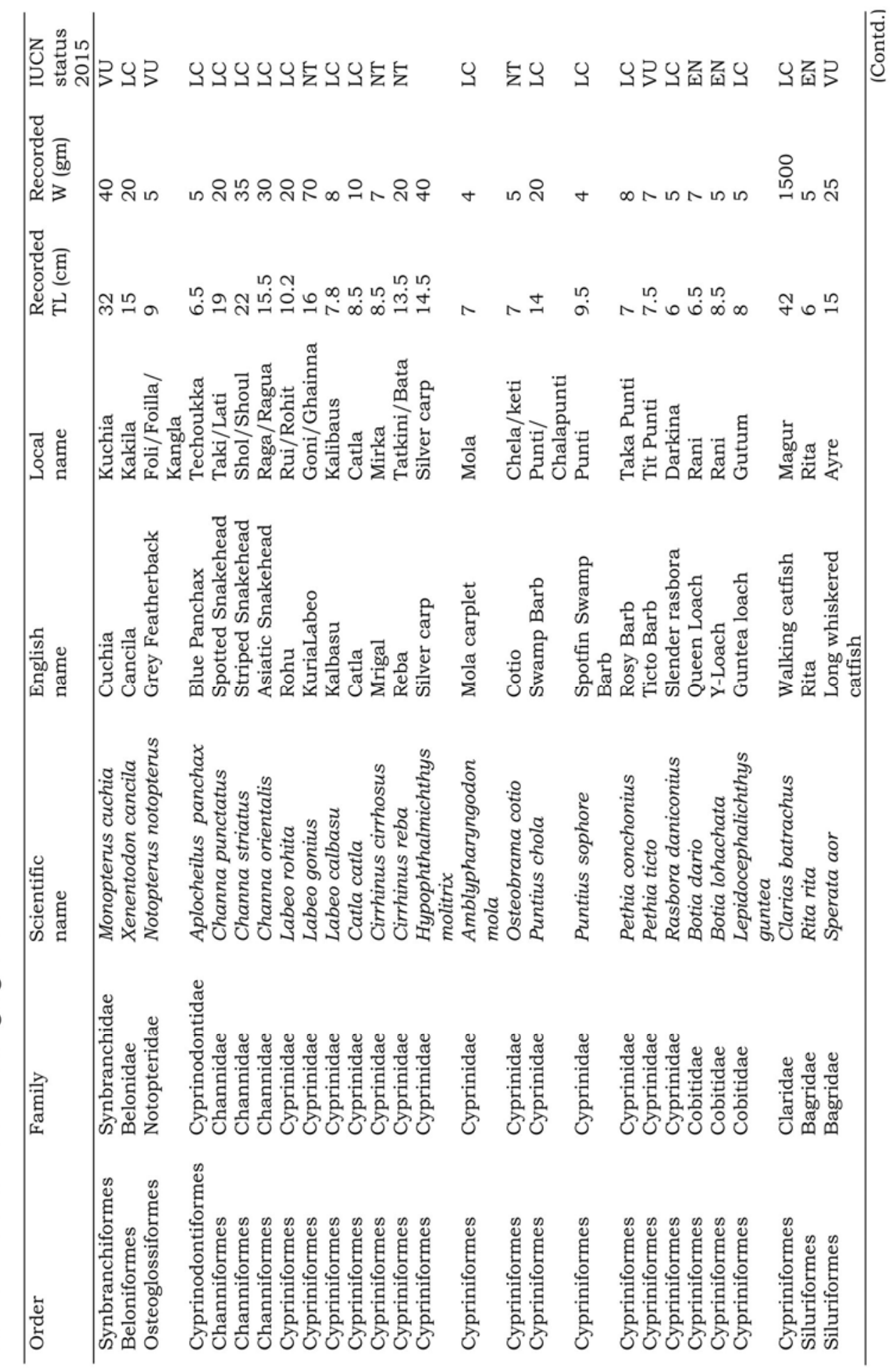




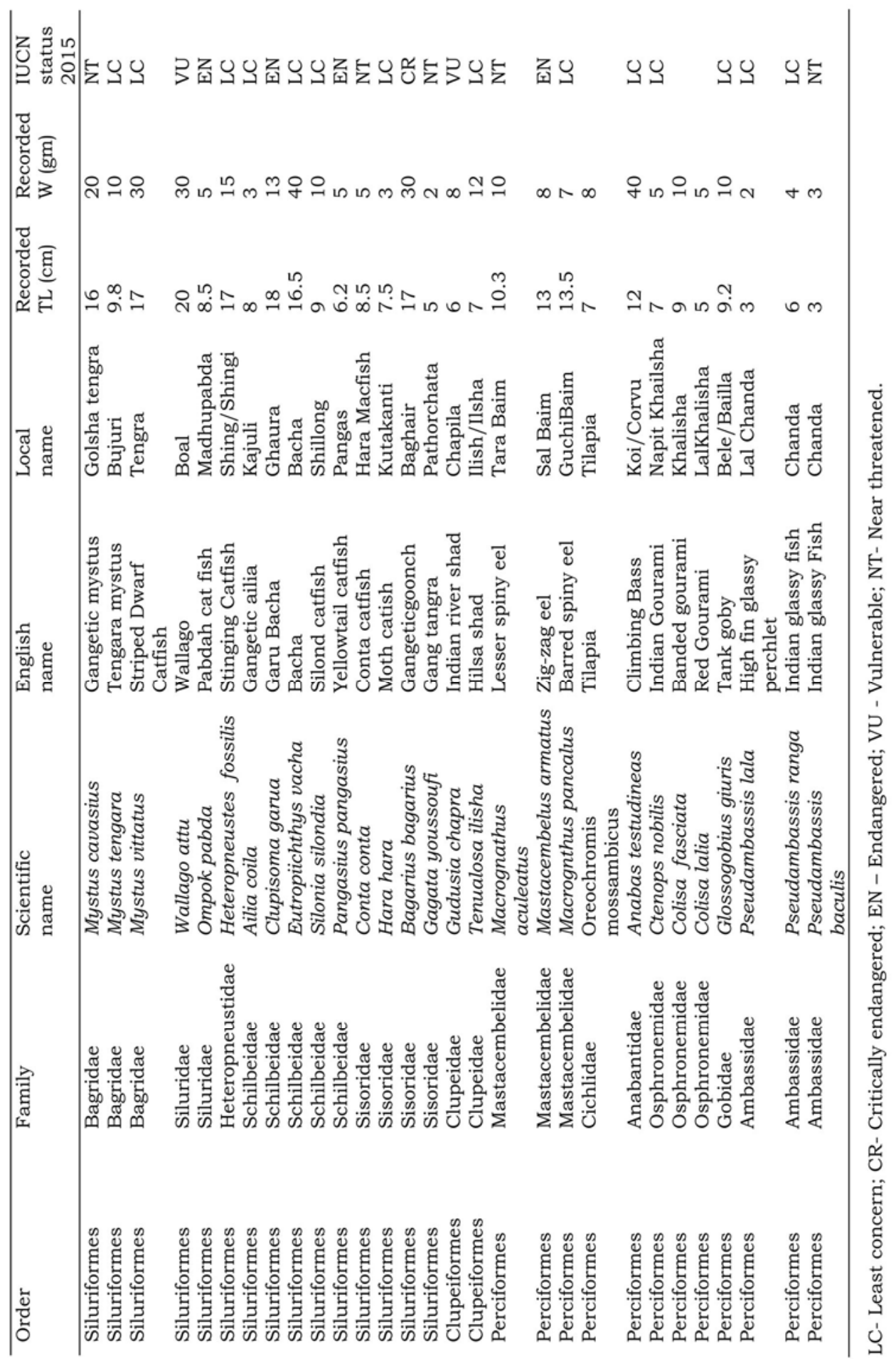


According to Shannon-Weiner diversity index of the collected fishes (seasonal) indicated a diverse distribution and the species richness variation across the river sites ranged from 1.825 to 3.843 (Table 2). As per Shannon Weiner index diversity were $\mathrm{H}^{\wedge^{\prime}}=3.843 ; \mathrm{D}=0.978$ for 56 species $(220$ individuals). The highest fish diversity was recorded during monsoon in the river, whereas lowest diversity was recorded during winter. The rarefaction curve indicates maximum species richness in monsoon and retreating monsoon period followed by post monsoon and winter season (Fig. 4). Descriptions of fish diversity in the upper Buriganga river are shown in Table 3. Maximum diversity variance $(7.616 \pm 2.76 \mathrm{Sd})$ was observed in the monsoon for 220 individual species. Lowest variance $(0.953 \pm 0.976 \mathrm{Sd})$ was recorded in the winter for 24 individual species (Table 3), Mean confidence interval was 1.493 in monsoon.

Table 2. Seasonal diversity, Shannon-Weiner index for fish

\begin{tabular}{lcc}
\hline Seasons & Species diversity & Shannon-Weiner diversity index \\
\hline Monsoon & 56 & 3.843 \\
Pre-monsoon & 8 & 2.019 \\
Post-monsoon & 38 & 3.578 \\
Winter & 7 & 1.825 \\
\hline
\end{tabular}

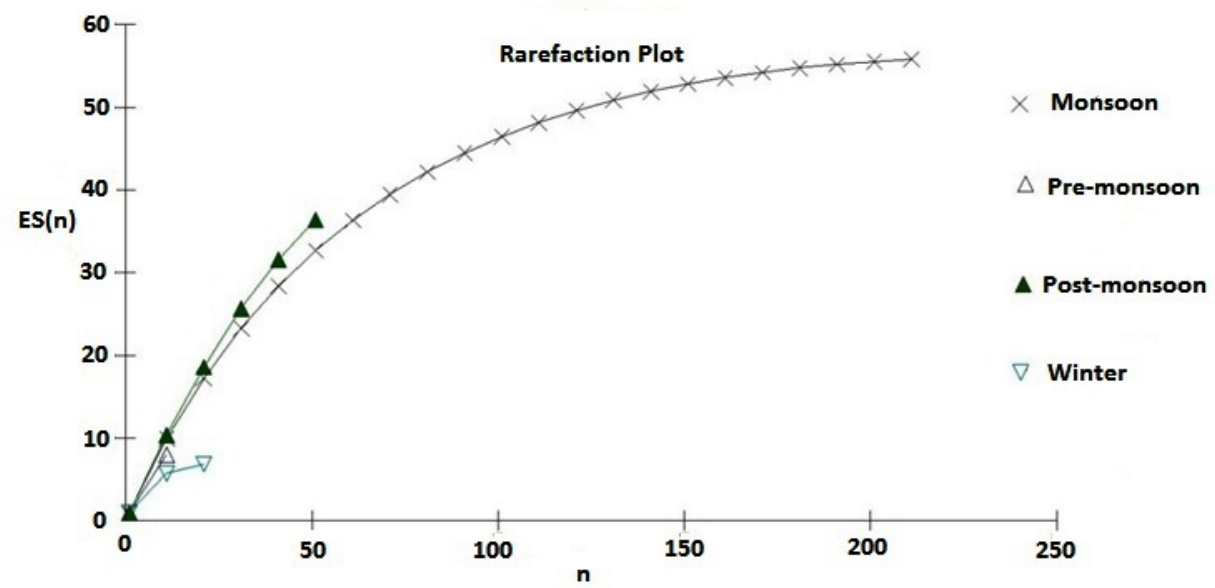

Fig. 4. Season-wise rarefaction curves, where $X$ axis shows individuals actually sampled and $Y$ axis shows estimation of the expected numbers of fish in the Buriganga river.

In the fishes, Cypriniformes were the most dominant order constituting (18) $32 \%$ of the total fish population followed by the Siluriformes (17) $30 \%$, Perciformes (12) 21\%, Channiformes (3) 5\%, Clupeiformes (2) 4\%, Synbranchiformes, Beloniformes, Osteoglossiformes, Cyprinodontiformes were the least 
Fish species diversity, fishing gears and crafts

Table 3. Seasonal fish diversity observed in the Buriganga river

\begin{tabular}{lcclcccc}
\hline Seasons & $\begin{array}{c}\text { Mean } \\
\text { individual }\end{array}$ & Variance & Sd & SE & $\begin{array}{c}\text { Total } \\
\text { individuals }\end{array}$ & $\begin{array}{c}\text { Total } \\
\text { species }\end{array}$ & $\begin{array}{c}\text { Mean } \\
\text { CI }\end{array}$ \\
\hline Monsoon & 2.2 & 7.616 & \pm 2.76 & 0.276 & 220 & 56 & 1.493 \\
Pre-monsoon & 0.11 & 0.159 & \pm 0.399 & 0.04 & 11 & 8 & 0.031 \\
Post-monsoon & 0.55 & 0.593 & \pm 0.77 & 0.077 & 55 & 38 & 0.116 \\
Winter & 0.24 & 0.953 & \pm 0.976 & 0.098 & 24 & 7 & 0.187 \\
\hline
\end{tabular}

Sd- Standard deviation, SE - Standard error, Mean CI - Mean confidence interval.

numerous orders constituting only $2 \%$ each of the total fish population (Fig. 5). Species distribution for the whole small indigenous fish community sampled revealed wide variation in distribution during all the seasons (Fig 6). Fish species numbers rose fairly from July. Most of the species was observed for 4 months from August to November (during monsoon and post monsoon). Extremely fewer species and lower number were recorded from December to June (3 fish species). Three species, namely Channa punctatus, Heteropneustes fossilis and Colisa fasciata were found abundantly throughout the year while Osteobrama cotio, Oreochromis mossambicus, Pseudambassis lala once in August only. Prominent migratory, commercially for both domestic and international species Tenualosa ilisha was recorded from the river. Tenualosa ilisha is an anadromus migratory fish of Bangladesh. Two exotic species Oreochromis mossambicus and Hypophthalmichthys molitrix, were observed in the monsoon season.

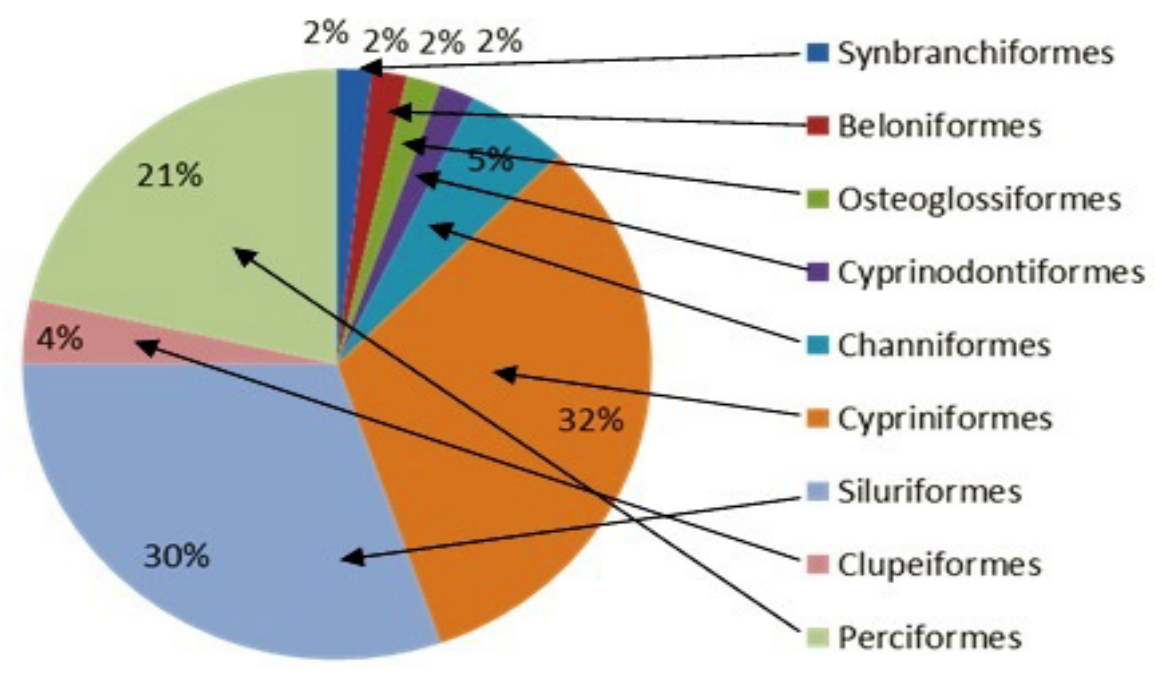

Fig. 5. Percentage of fish species composition under different orders found in the present study. 
Fishing Gear and Craft : During the study period a total of 12 different types of fishing gears of two categories (active and passive gear) were observed to harvest fish in the study area (Table 5). Major categories of gears include nets, traps and hooks. The monthly gear diversity was also observed in study area. The maximum number of gears were observed to operate in October (78 gears) and the minimum in March and April (1 gear) were used for fish capture in the river. The highest number of gears were recorded as: 17 Borsi and 3 Dahun Borsi in October, 15 Dharma Jal in August, 12 Veshal Jal in September, 7 Current Jal and 3 Ber Jal in October, 2 Veshal Dhingi and Bhndi Jal in July to October, 3 Thala Jal in October to November and Cast net (Jaki Jal) was found throughout the year which have been used as permanent, temporary and subsistence fishing in the river. Maximum number of cast net (11) have been operated in the river in October 2013 (Fig. 7). Different mesh size were recorded of the fixed beg net (Bandi Jal), lift net (Veshal Jal), boat lift net (Veshal Dingi Jal) in the river (Table 5). Fixed beg net has been operated at Kamrangichar within current water in the month of July to October 2013. A total of 5 different types of boat of 2 categories (engine boat and non-engine boat) were used for fish capture in the Buriganga River (Table 4). Kosa boat, Jaila boat, Veshal dingi boats were used with engine and Bandi Jal, Veshal Dingi Jal operated from those boats in the study area. Kosa boat and Dingi boat have been used as nonengine boat which most of the Current Jal and Khepla Jal were operated in the river. Usually jackfruit wood, jamrul wood, bamboo materials were used to make craft.

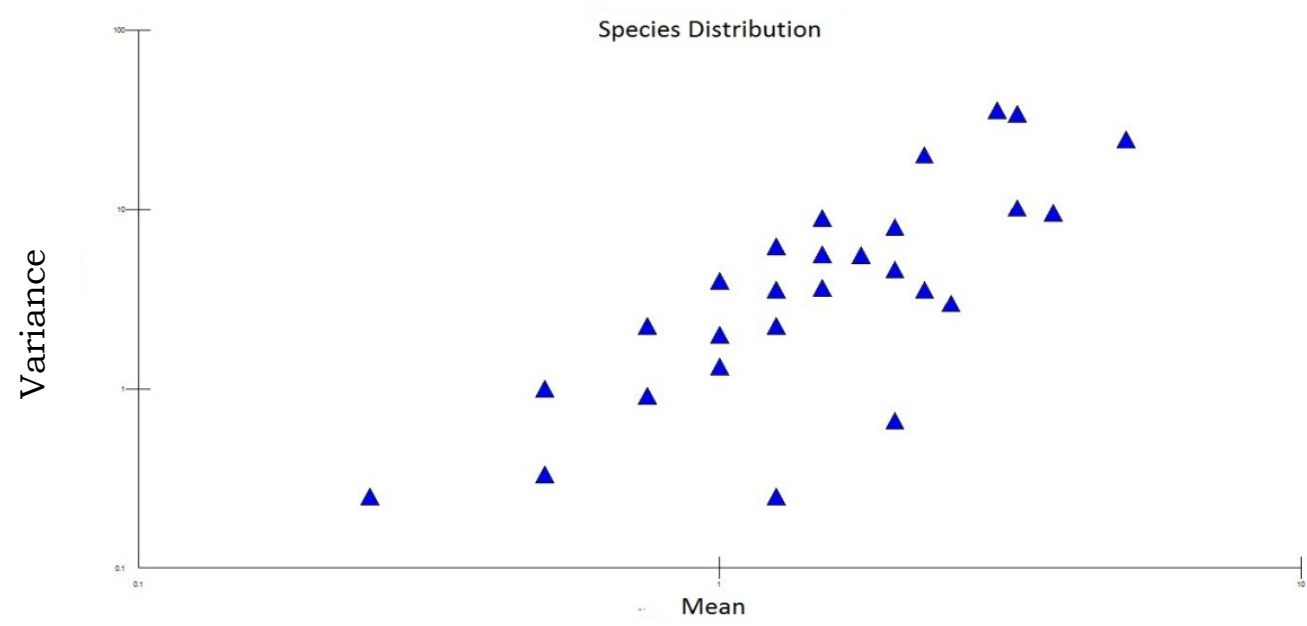

Fig. 6. Species distribution plot for fish community sampled from the Buriganga river. 
Table 4. Different types of crafts used for fish capture in the Buriganga river

\begin{tabular}{|c|c|c|c|c|c|c|}
\hline \multirow[t]{2}{*}{$\begin{array}{l}\text { Types of } \\
\text { craft }\end{array}$} & \multirow[t]{2}{*}{$\begin{array}{l}\text { Craft } \\
\text { name }\end{array}$} & \multicolumn{2}{|c|}{$\begin{array}{l}\text { Measurement of } \\
\text { the craft }\end{array}$} & \multirow[t]{2}{*}{$\begin{array}{l}\text { Materials used for } \\
\text { made }\end{array}$} & \multirow[t]{2}{*}{$\begin{array}{l}\text { Gear used } \\
\text { in craft }\end{array}$} & \multirow[t]{2}{*}{$\begin{array}{c}\text { Operator } \\
\text { person }\end{array}$} \\
\hline & & $\begin{array}{l}\text { Length } \\
(\mathrm{ft})\end{array}$ & $\begin{array}{c}\text { Wide } \\
\text { (ft) }\end{array}$ & & & \\
\hline \multirow[t]{3}{*}{$\begin{array}{l}\text { Engine } \\
\text { boat }\end{array}$} & $\begin{array}{l}\text { Kosa } \\
\text { boat }\end{array}$ & 32 & 8 & Jamrul wood, bamboo & Bandi Jal & $2-4$ \\
\hline & $\begin{array}{l}\text { Jaila } \\
\text { boat }\end{array}$ & 37 & 8 & Jamrul wood, bamboo & Bandi Jal & $2-4$ \\
\hline & $\begin{array}{l}\text { Veshal } \\
\text { Dingi } \\
\text { boat }\end{array}$ & 40 & 10 & $\begin{array}{l}\text { Jackfruit wood, Jamrul } \\
\text { wood, Bamboo }\end{array}$ & Veshal Dingi Jal & $3-5$ \\
\hline \multirow[t]{2}{*}{$\begin{array}{l}\text { Non- } \\
\text { engine } \\
\text { boat }\end{array}$} & $\begin{array}{l}\text { Kosa } \\
\text { boat }\end{array}$ & $14-15$ & $2.5-3.5$ & $\begin{array}{l}\text { Jackfruit wood, Jamrul } \\
\text { wood, bamboo }\end{array}$ & $\begin{array}{l}\text { Khepla Jal, Berjal, } \\
\text { current Jal, Borsi, } \\
\text { chai, etc }\end{array}$ & $1-2$ \\
\hline & $\begin{array}{l}\text { Dingi } \\
\text { boat }\end{array}$ & 15 & 5 & $\begin{array}{l}\text { Jackfruit wood, Jamrul } \\
\text { wood, bamboo }\end{array}$ & $\begin{array}{l}\text { Veshal Jal, Ber Jal, } \\
\text { etc }\end{array}$ & $1-2$ \\
\hline
\end{tabular}

Table 5. Different types of nets, traps, hook and line used for fishing in the Buriganga River

\begin{tabular}{|c|c|c|c|c|c|c|}
\hline \multirow{2}{*}{$\begin{array}{l}\text { Types of } \\
\text { gear/net }\end{array}$} & \multirow{2}{*}{$\begin{array}{l}\text { Local name } \\
\text { of gear }\end{array}$} & \multicolumn{3}{|c|}{ Measurement } & \multirow{2}{*}{$\begin{array}{l}\text { No. of } \\
\text { operating } \\
\text { person }\end{array}$} & \multirow[t]{2}{*}{ Location } \\
\hline & & $\begin{array}{c}\text { Length } \\
(\mathrm{ft})\end{array}$ & $\begin{array}{c}\text { Width } \\
\text { (ft) }\end{array}$ & $\begin{array}{c}\text { Mesh size } \\
(\mathrm{cm})\end{array}$ & & \\
\hline Seine net & Ber Jal & $250-500$ & $20-30$ & $0.5-3.5$ & $5-6$ & $\mathrm{~B}, \mathrm{C}$ \\
\hline Cast net & $\begin{array}{l}\text { Khepla } \\
\text { Jal/Jaki Jal }\end{array}$ & $12-15$ & $40-90$ & $1.5-2.0$ & 1 & $\mathrm{~A}, \mathrm{~B}, \mathrm{C}$ \\
\hline Lift net & Dharma Jal & $12-15$ & $12-15$ & 1.5 & 1 & $\mathrm{~A}, \mathrm{~B}, \mathrm{C}$ \\
\hline Lift net & Veshal Jal & $40-50$ & $40-45$ & $1.5-2.0$ & 1 & $\mathrm{~A}, \mathrm{~B}, \mathrm{C}$ \\
\hline Gill net & Current Jal & $750-1000$ & $9-10$ & $1.5-2.0$ & $1-2$ & $\mathrm{~B}, \mathrm{C}$ \\
\hline $\begin{array}{l}\text { Fixed beg } \\
\text { net }\end{array}$ & Bhndi Jal & 450 & 40 & $1-7.0$ & $3-5$ & B \\
\hline $\begin{array}{l}\text { Boat lift } \\
\text { net with } \\
\text { engine }\end{array}$ & $\begin{array}{l}\text { Bashal Dinghi } \\
\text { Jal }\end{array}$ & $40-50$ & $20-30$ & $1-3.5$ & 5 & $\mathrm{~A}, \mathrm{~B}, \mathrm{C}$ \\
\hline Push net & Thala Jal & 5 & 2.5 & $0.5-1.5$ & 1 & $\mathrm{~A}, \mathrm{~B}, \mathrm{C}$ \\
\hline Box trap & $\begin{array}{l}\text { Paran/Chai } \\
\text { Chai }\end{array}$ & $\begin{array}{l}3 \\
1.5\end{array}$ & $\begin{array}{l}1.5 \\
1.5\end{array}$ & $\begin{array}{l}\text { Bamboo stick } \\
\text { Bamboo stick }\end{array}$ & $\begin{array}{l}1 \\
1\end{array}$ & $\begin{array}{l}\mathrm{B}, \mathrm{C} \\
\mathrm{B}, \mathrm{C}\end{array}$ \\
\hline $\begin{array}{l}\text { Hook and } \\
\text { line }\end{array}$ & $\begin{array}{l}\text { Local name of } \\
\text { gear }\end{array}$ & No. of hook & $\begin{array}{l}\text { Use of } \\
\text { bait }\end{array}$ & Boat needed & $\begin{array}{l}\text { No. of } \\
\text { operating } \\
\text { person }\end{array}$ & Location \\
\hline Hand line & Chip Barshi & $1-2$ & $\begin{array}{l}\text { Red } \\
\text { Earthwo- } \\
\text { rms, } \\
\text { prawn }\end{array}$ & $\begin{array}{l}\text { No boat } \\
\text { needed }\end{array}$ & 1 & $\mathrm{~A}, \mathrm{~B}, \mathrm{C}$ \\
\hline & Boal Barshi & $1-2$ & $\begin{array}{l}\text { Earthwo- } \\
\text { rms }\end{array}$ & $\begin{array}{l}\text { No boat } \\
\text { needed }\end{array}$ & 1 & $\mathrm{~B}, \mathrm{C}$ \\
\hline Long line & Hajar Barshi & 1000 & $\begin{array}{l}\text { Red } \\
\text { Earthwo- } \\
\text { rms, } \\
\text { prawn }\end{array}$ & Boat needed & $1-2$ & $\mathrm{~B}, \mathrm{C}$ \\
\hline
\end{tabular}


The present study is the first of its kind for the River Buriganga on fish diversity and conservation priority in view of interlinking. The number and monthly variation of species recorded result with total length clearly indicating a loss of fish biodiversity in the Buriganga river. The number of species and its maximum size of fishes are very important for sustainable management in the water body. Most of the people depend on reverien fisheries for their livelihood but fishermen get less fishing opportunity in the river system. A total of 52 fishes belonging to 15 families and 33 genera were recorded during January, 2013 to December, 2014 from the River Brahmaputra in Assam, north-eastern India (Baishya et al. 2016). Fish diversity in the upper Brahmaputra river, India was maximum diversity variance $(140.39 \pm 11.85 \mathrm{Sd})$ was observed in the monsoon season for 49 species (680 individuals). Lowest variance (66.35 \pm 8.15 Sd) was recorded in the winter season with 423 individuals (45 species) (Baishya et al. 2016) and currently 56 fish were recorded from the upper Buriganga river. Among the fishes Tenualosa ilisha also migrates in the river to breed in the rainy season but they cannot visit properly due to water pollution and different ages of people collected fish from the fishermen. A total of 80 species of fish under 9 orders and 24 families were recorded in the Padma river, NW Bangladesh (Rahman et al. 2012). Fish species size (length, weight and number) has very limited presence in the samples collected as well as the fishermens' catches. Large fishes (Table 1), which are more valuable, modifies the size structure and functioning of fish assemblages, with consequences for productivity and resilience of some stocks are highly limited in these water bodies even when fish are available. The size of fish depends on the availability of food and habitat. The length or other physical dimension including weight of fish can be influenced by environmental factor (Shukor et al. 2008, Jobling et al. 2002). One of the notable factors in the study is that deliberately or accidentally introduction of exotic fish species has occurred in this river as is evidenced by their presence. As this exotic fish is a prolific breeder, it can compete and replace the native fishes, over the entire stretch of the river within a limited period of time which may lead to reduce biodiversity and the ecosystem's ability to adapt to natural or human-induced changes. Therefore, it is better to prevent them from invading and becoming established to reduce the ecological impacts of exotic species in this water body.

Seasonal changes in the fisheries of rivers are principally determined by cyclical changes in discharge, water velocity and water level which in turns greatly influence the relative abundance of different species of fish. The results indicated clear seasonal patterns in the variation of total monthly fish species number recorded in this river fluctuated extreme widely among different 
months. It can be seen that the higher number of species were captured from July to November with peaks in August (Fig. 3). Correlation analysis between water depth and fish species number $(r=0.74)$ and fishing activities $(r=0.96)$ showed strong correlation. Numbers rose fairly from July when floodwaters also rose during monsoon (July-September) (Fig. 2). So peak observed in August may be associated with monsoon because there is different kind of fishes which breeding cycle and migrations up and down river related with monsoon. These results support that the fish species composition was a great extent influenced by the flood water situation. This same characteristic was noted in rivers Jamuna and Padma (FAP - 17, Vol. No. 10, 1994). However, fish species gradually decreased from August to November when gear number gradually increased in these months. The number of results indicated that reduced number of fish in August to November may be associated with increased fishing activities. But fish species and gears numbers sharply decreased staring from November. This statuesque continues till June with more or less constant numbers of fish and gear, respectively. Data indicated that there was almost zero number of catches during these periods. Water level and flow also sharply reduced during this period (Fig. 2).

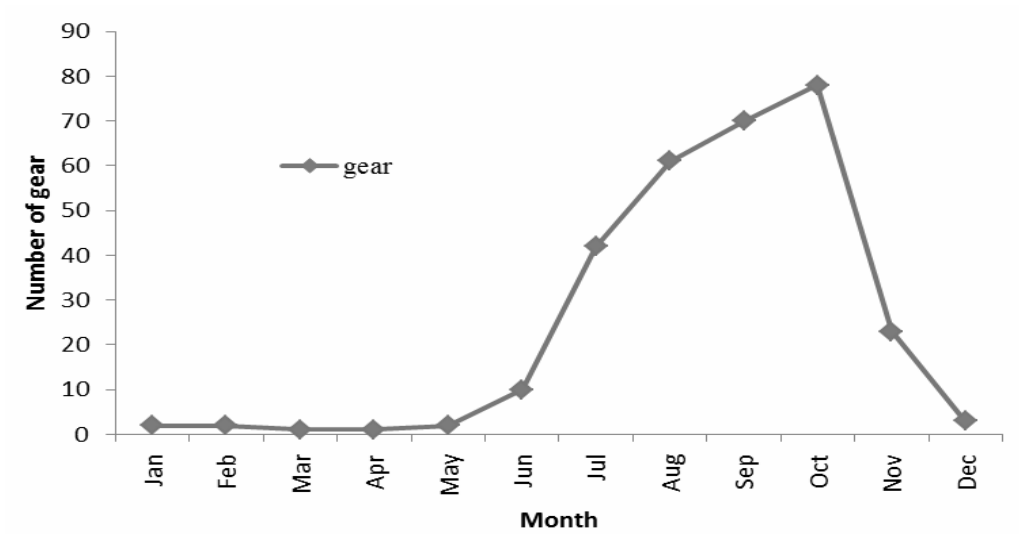

Fig. 7. Monthly total number of gear (active and passive) operated in the Buriganga river.

Furthermore, data indicated that only Channa puctatus, Heteropneustes fossilis and Anabas testudinus were observed during dry and pre-monsoon. $H$. fossilis can respire aerially by gulping in air at various intervals when the oxygen content of water is low (Munshi 1993). The air-breathing apparatus of these species enables it to exist in almost any kind of water. Catfish have a broad environmental tolerance and can sustain the harsh conditions during the dry season (Ahmed 2008). Catfish include members of the Clariidae, Siluridae 
and Ophiocephalidae. However, presence of these species during dry and premonsoon periods indicated that they cannot survive due to water pollution. Environmental degradation and habitat loss is reported as the major causes of declining fisheries in most rivers under stress situation (Coates et al. 2004). Furthermore, the amount of catch depends upon its productivity of the fishing grounds (Naidu 1939). Therefore, the extreme lower number and diversity of fishes (almost zero) were recorded in dry and pre-monsoon period mainly due to adverse water quality of this river not for increased fishing activities. However, considering the above mentioned facts, it is noted that observed almost zero catch from December to June caused by reduced water flow and adverse water quality which may lead towards extinct of fishes from this river at least in this period. The survey revealed that a wide variety of fishing gears and crafts were operated with clear seasonal patterns of fishing methods. Entering/rising of floodwaters in the study area stimulated an increase in fishing activities using different fishing methods and species targeted by these methods. Some of the gears were selective for a particular species, whereas others account for a number of species caught during operation giving multispecies nature of the fishing. Long line operated from drifting or anchored boats.

The result suggests that best water level, flow and freshwater ecology can increase fish diversity with production. Also suggests that both indirect and non-use values should be given due consideration by the policy makers before taking any development project or program at the river. For the conservation of these fishes of the upper Buriganga river, strategies such as control of water pollution, illegal fishing and development, control of ship, water bus etc. In the breeding season fishing activities must be stopped in the river. More studies, on biology and population dynamics of commercially exploited species are also needed to formulate a sustainable management strategy for this river. The study shows the need of improved public policies aiming at the conservation of its ichthyofauna diversity, as well as programs of environmental education to raise the awareness of local settlers regarding their land and its fishes, dumping of municipal and industrial wastes, continuous water flow almost throughout the year etc.

Acknowledgements: The authors are thankful to the fishermen and local people in the survey area for their sincere cooperation. This work was funded by Jagannath University Research Grants for 2012-2013 and Special Research Grant of the Ministry of Science and Technology, Government of Bangladesh. They thank the authority of the Department of Zoology, Jagannath University, Dhaka and MAB'S Lab of Biodiversity Conservation and Fisheries Research Center (BCFRC) for providing laboratory facilities. 


\section{LITERATURE CITED}

AHMED, M.K., BAKI, M. A., KUNDU, G. K., ISLAM, M.S., ISLAM, M. M. and HOSSAIN, M.M. 2016. Human health risks from heavy metals in fish of Buriganga river, Bangladesh. Springerplus $\mathbf{5}(1)$ : 1697. doi: 10.1186/s40064-016-3357-0

AHMED, N. 1962. Fishing gear of East Pakistan, Directorate of Fisheries. Dacca: East Pakistan Govt. Press.

AHMED, M.S. 2008. Assessment of fishing practices on the exploitation of the Titas floodplain in Brahmanbaria, Bangladesh. Turkish Journal of Fisheries and Aquatic Sciences 8: 329-334

ALEYA, B. and SEHRIN, S. 2013. Levels of heavy metals in different tissues of pigeon (Columba livia) of Bangladesh for Safety Assessment for Human Consumption. Bangladesh Pharmaceutical Journal 16(1): 81-87.

ALI, M.Y., AMIN, M.N. and ALAM, K. 2008. Ecological health risk of Buriganga river, Dhaka, Bangladesh. HYDRO NEPAL | ISSUE NO. 3.

BAISHYA, R.A., BASUMATARY, S., KALITA, H.K., TALUKDAR, B., DUTTA, A. and SARMA, D. 2016. Present status and diversity of small indigenous fish species (SIS) in the upper reaches of river Brahmaputra in Assam, north-eastern India. Indian J. Fish 63(1): 1-7.

COATES, D., BOIVIN, T., DARWALL, W.R.T., FRIEND, R., HIRSCH, P., POULSEN, A.F., QUIRÓS, R., VISSER, T.A.M. and WALLACE, M. 2004. Information, knowledge and policy. pp. 93-118 in R.L. Welcomme and T. Petr (eds.) Proceedings of the Second International Symposium on the Management of Large Rivers for Fisheries, Volume 1. FAO, Bangkok. 356 pp.

CHOVANCE, A.R., HOFFER and SCHIEMER, F. 2003. Fish as bioindicators. In: B.A. Market, A.M. Breure, H.G. Zechmeiser, (eds) Bioindicatos and Biomonitors. pp. 639-675.

DARWALL, W.R.T. and VIE, J.C. 2005. Identifying important sites for conservation of freshwater biodiversity: extending the species based approach. Fish Manag Ecol. 12: 287-293.

DUDGEON, D., ARTHINGTON, A.H., GESSNER, M.O., KAWABATA, Z.I., KNOWLER, D.J., LEVEQUE, C., NAIMAN, R.J., PRIEUR, R.A.H., SOTO, D., STIASSNY, M.L.J. and SULlIVAN, C.A. 2006. Freshwater biodiversity: importance, threats, status and conservation challenges. Biol. Rev. 81:163-182.

FLOOD ACTION PLAN 1994. Fisheries studies and pilot project, Report Prepared for the Government of Bangladesh. UK: Overseas Development administration. 17(10): 68-70.

HOSSAIN, M.Y., RAHMAN, M.M., JEWEL, M.A.S., AHMED, Z.F., AHAMED, F., FULANDA, B. and OHTOMI, J. 2012a. Conditions and form-factor of the five threatened fishes from the Jamuna (Brahmaputra river distributary) River, northern Bangladesh. Sains Malaysiana 41(6): 671-678.

HOSSAIN, M.Y., RAHMAN, M.M., FULANDA, B., JEWEL, M.A.S., AHAMED, F. and OHTOMI, J. 2012b. Length-weight and length-length relationships of five threatened fish species from the Jamuna (Brahmaputra river tributary) river, northern Bangladesh. J. Applied Ichthyology 28(2): 275-277.

ISLAM, M.M., AKHTAR, M.K. and MASUD, M.S. 2006. Prediction of environmental flow to improve the water quality in the river Buriganga. In: Proceedings of the 17th IASTED International Conference on Modelling and Simulation, Montreal, QC, Canada.

JOBling, S., COEY, S., WHITMORE, J.G., KIME, D.E., VAN, L.K.J.W., ALliSTER, B.G., BERESFORD, N., HENSHAW, A.C., BRIGHTY, G., TYLER, C.R. and SUMPTER, J.P. 2002. Wild in tersex roach (Rutilus rutilus) have reduced fertility. Biol. Repro'd. 67:515-524.

KANG, B., HE, D., PERRETT, L., WANG, H., HU, W., DENG, W. and WU, Y. 2009. Fish and fisheries in the Upper Mekong: current assessment of the fish community, threats and conservation. Rev Fish Biol. Fish 19: 465-480. 
KHORSHED, A. 2008. Cost-benefit analysis of restoring Buriganga river, Bangladesh. Water Resources Development. 24(4): 593-607.

LAFFAille, P., ACOU, A., GUILlOUET, J. and LEGULT, A. 2005. Temporal change in European eel, Anguilla anguilla, stock in a small catchment after installation of fish passes. Fish Manag. Ecol. 12:123-129.

MUNSHI, J.S.D. 1993. Structure and function of the air breathing organs of Heteropneustes fossilis; in Advances in fish research I (ed.) B.R. Singh (Delhi: Narendra Publishing House). pp. 99-138.

MONIRUZZAMAN, M. 2009. Study on temporal variation of physico-chemical Parameters of Buriganga River Water. Bangladesh J. Sci. Ind. Res. 44(3): 327-334.

MOHIUDDIN, K.M., OGAWA, Y. Z.H.M., OTOMO, K. and SHIKAZONO, N. 2011. Heavy metals contamination in water and sediments of an urban river in a developing country. Int. J. Environ. Sci. Technol. 8: 723-736.

MIHIR, L.S., MAHBUBAR, R.K., MOHAMMAD, A. and SIRAJUL, H. 2009. Bacterial load and chemical pollution level of the river Buriganga, Dhaka, Bangladesh. Bangladesh J. Bot. 38(1): 87-91.

NAIDU, M.R. 1939. Report on survey of the fisheries of Bengal. Calcutta Govt. Printer.

NOURI, J., FATEMI, M.R., DANEKAR, A., FAHIMI, F.G. and KARIMI, D. 2009. Determination of environmentally sensitive zones along Persian Gulf coastlines through geographic information system. J. Food Agr. Environ. 7(2): 718-725.

RAHMAN, A.K.A. 1989. Freshwater Fishes of Bangladesh. 1st (Ed). Bangladesh. Zoological Society of Bangladesh.

RAHMAN, M.M., HOSSAIN, M.Y., AHAMED, F., FATEMATUZZHURA, SUBBA, B.R., ABDALLAH, E.M. and OHTOMI, J. 2012. Biodiversity in the Padma distributary of the Ganges river, Northwestern Bangladesh: Recommendations for Conservation. World J. Zool. 7(4): 328-337.

SAHA, P.K. and HOSSAIN, M.D. 2011. Assessment of heavy metal contamination and sediment quality in the Buriganga river, Bangladesh 2nd International Conference on Environmental science and technology IPCBEE Vol. 6. LACSIT press Singapore. pp. 384-388.

SALA, O.E., CHAPIN, III F.S., ARMESTO, J.J., BERLOW, R., BLOOMFIELD, J., DIRZO, R. and WALL, D.H. 2000. Global biodiversity scenarios for the year 2100. Sci. 10: 287 (5459), 1770-1774.

SARKAR, U.K., PATHAK, A.K. and LAKRA, W.S. 2008. Conservation of freshwater fish resources of India: new approaches, assessment and challenges. Biodivers Conserv. 17: 2495-2511.

SARKER, M.A.K. 2005. Study on the accumulati on and seasonal variation of trace metals in water, Sediment and some fishes of the Buruganga river. Department of Zoology, Dhaka University. pp. 1-4.

SIDDIQUI, K.U., ISLAM, KABIR, M.A., AHMED, S.M.H.M., AHMED, A.T.A., RAHMAN, A.K.A., HAQUE, E.U., AHMED, Z.U., BEGUM, Z.N.T., HASSAN, M.A., KHONDKER, M. and RAHMAN, M.M. 2007: Encyclopedia of Flora and Fauna of Bangladesh, Vol. 23, Freshwater Fishes. Dhaka: Asiatic Society of Bangladesh.

SHUKOR, M.N., SAMAT, A., AHMAD, A.K. and RUZIATON, J. 2008. Comparative analysis of length weight relationship of Rasbora sumatrana in relation to the physicochemical characteristics in different geographical areas in Peninsular Malaysia, Malaysian Applied Biology 37(1): 2129.

WINEMILLER, K.O. 1989. Patterns of variation in life history among South American fishes in seasonal environments. Oecologia 81: 225-241. 